при выполнении лабораторных работ, можно приобрести те навыки, которые помогают использовать теоретические знания. Благодаря проведению различных экспериментов, легче уяснить различные понятия химии, объяснить те или иные явления.

Умение применять знания при выполнении химического эксперимента можно считать сформированным, если студент может правильно провести опыты, предусмотренные программой, самостоятельно осуществить необходимые наблюдения, достичь поставленной цели и сделать выводы, если он соблюдает правила поведения в лаборатории, не нарушает технику безопасности, а при проведении эксперимента не нуждается в помощи.

Любое знание без эксперимента - формальное знание. На теоретическом уровне достигается высший синтез знаний в форме научной теории. Основоположник отечественной науки М. В. Ломоносов отмечал: «Опыт ценнее тысячи мнений, рожденных воображением», а академик Л. Д. Ландау говорил: «Опыт - верховный судья теории».

Эксперимент позволяет установить причинно-следственные связи между явлениями. Он позволяет выяснить кинетику, динамику процессов и их энергетическую сущность.

Химический эксперимент придает особую специфику предмету химии. Он является важнейшим способом осуществления связи теории с практикой путем превращения знаний в убеждения.

Эксперимент - важнейший путь осуществления связи теории с практикой при обучении химии, превращения знаний в убеждения [7].

$$
* * *
$$

1. Ермаханов М.Н., Журхабаева Л.А., Адырбекова Г.М., Асылбекова Г.Т., Сабденова У.О., КуандЫкова Э.Т. ХИМИЧЕСКИЙ ЭКСПЕРИМЕНТ И ЕГО РОЛЬ В МЕТОДИКЕ ОБУЧЕНИЯ ХИМИИ // Международный журнал прикладных и фундаментальных исследований. - 2016. - № 13. - C. 398-399;

2. Атоев Э.Х. Химический эксперимент как важный аспект преподавания химии в академических лицеях и профессиональных колледжах / Э.Х. Атоев, М.Х. Холлиева, М.Р.Кувончева.- Текст: непосредственный // Молодой ученый.- 2015.- №3 (83).- C.727-728.- URL: https://moluch.ru/archive/83/15165/ (дата обращения : 11.12.2020).

3. Роль лаборатории для обучения химии, автор Ардистони Марям Сироджиен, рубрика Педагогика. Опубликовано в Молодой ученый №2 (49) февраль 2013г.

4. Верховский В.Н., Смирнов А.Д. Техника химического эксперимента. Т. 1. М., 1973;

5. Бахтиярова Ю.В., Миннуллин Р.Р., Галкин В.И. Основы химического эксперимента и занимательные опыты по химии: учебное пособие для вузов и школ / Ю.В. Бахтиярова, Р.Р. Миннуллин, В.И. Галкин. - Казань: Изд-во Казан. ун-та, 2014. - 144 с.

6. Воскресенский П.И. Техника лабораторных работ, М., Изд-во «Химия», 1973, С.717.

7. Амирова А.Х. Демонстрационный и ученический эксперимент в практике обучения химии // Химия в школе. 2004. - №6. - С. $62-66$.

\title{
Ивашов О.А.
}

\section{Современные проблемы обучения иностранному языку спортсменов-} профессионалов

ФГАОУ ВО «Северо-Кавказский федеральный университет» (Россия, Ставрополь)

\section{Аннотация}

В статье рассматриваются современные проблемы обучения иностранному языку спортсменов-профессионалов и предлагаются пути повышения эффективности обучения.

Ключевые слова: коммуникативная компетенция, иноязычная коммуникация, профессиональное общение. 
Abstract

The article deals with modern problems of teaching a foreign language to professional athletes and suggests ways to improve the effectiveness of training.

Keywords: communicative competence, foreign language communication, professional communication.

Английский язык как иностранный изучается в качестве общеобразовательной дисциплины во всех типах учебных заведений, и детско-юношеские спортивные школы не являются исключением. Однако следует отметить, что в том виде, в каком он преподается сейчас, иностранный язык не носит специфического спортивноориентированного характера. Стоит отметить, что на практике нет четкого разграничения между курсами английского языка для академических и профессиональных целей.

Умение общаться на иностранном языке в устной форме выступает как важное качество любого специалиста. Выработка этого умения предусматривается программой предмета «Английский язык», однако спортсмены не владеют умениями устного общения в достаточной для практического использования иностранного языка степени. Одной из основных причин этого можно назвать отсутствие профессиональной направленности обучения. Научиться говорить на иностранном языке о том, что интересно, полезно и нужно для будущего специалиста - вот главная движущая сила, мотив, побуждающий человека вступить в акт коммуникации. Поэтому одной из основных проблем является подбор языкового материала для организации спортивноориентированного обучения. Решение данной проблемы предполагает исследование специфических особенностей общения спортсменов и учет этих особенностей в организации учебного процесса. Необходимо выявить закономерности и особенности речи спортсменов, которые проявляются в типичных способах выражения коммуникативных намерений.

Специфика речи спортсменов заключается в использовании большого количества спортивных терминов, команд, в совпадении значений интернациональной профессиональной лексики в английском и русском языках. Часто встречаются лексические единицы, о значении которых легко догадывается спортсмен, даже слабо владеющий английским языком: judo - дзюдо; extreme sports - экстремальные виды спорта; to pass - передавать, давать пас; goalkeeper - вратарь; penalty - пенальти, штрафной удар; a halfback - полузащитник; a fullback - защитник; a forward центральный нападающий; a center forward - центральный нападающий; a referee рефери, судья.

Обычно не вызывают затруднений и названия видов спорта, как традиционных (football, tennis, basketball, volleyball), так и новых, появившихся в сравнительно недавнее время (windsurfing - виндсерфинг, ice-diving - айсдайвинг, snowboarding сноубординг, white-water rafting - спуск на плотах по горным рекам, parachuting парашютный спорт и т.п.).

Созвучность профессиональной лексики способствует определенной автоматизации речемыслительных реакций, что дает возможность предельно конкретизировать обучение. Обеспечив спортсмена некоторым минимумом речевых моделей, мы можем добиться свободного порождения высказываний по различной профессиональной и бытовой тематике.

Тщательно подобранный лексический минимум будет хорошим организующим началом при использовании аутентичных материалов.

Обучение должно строиться на хорошо продуманном грамматическом материале. Как показывают наблюдения за спортивными соревнованиями, комментариями матчей и пр., грамматически речь спортсменов оформлена достаточно просто. Нет сложных в грамматическом плане конструкций, громоздких оборотов речи. 
Спортсмену, выезжающему за рубеж, прежде всего необходимо владеть определенным набором фраз общего и профессионального характера, уметь понимать обращенную к нему речь на бытовом уровне, команды тренера, судьи, обращение партнеров по команде и пр. и уметь адекватно реагировать на них. Поэтому мы считаем, что нет необходимости знакомить школьников со всем многообразием английских грамматических явлений. Достаточно будет выделить наиболее частотные грамматические формы и конструкции, характерные для спортивного языка: простые видовременные формы глагола, спряжение глагола to be в настоящем и прошедшем времени, простые предложения в изъявительном и повелительном наклонении. Такой сокращенный грамматический набор будет служить стимулом для формирования умений вести свободный разговор и пользоваться специфическими для спортивной речи способами оформления мысли, так как не будет отвлекать говорящего на размышления по поводу того, правильно ли его высказывание оформлено грамматически.

В содержание обучения общению на иностранном языке должны войти определенные коммуникативные акты, представленные в виде образцов, доступных для понимания и продуцирования. Языковые средства, необходимые и достаточные для овладения умениями создавать коммуникативные акты, следует отбирать в соответствии со следующими факторами: сфера, ситуация общения, коммуникативное намерение. Важным критерием при отборе языковых средств является их тематическая отнесенность.

Незнание специфических особенностей спортивно-ориентированного стиля речи значительно затрудняет понимание услышанного и адекватную реакцию на обращенную к коммуниканту речь. В связи с этим необходимо рассмотреть основные стилевые особенности речи спортсменов, которые могут вызвать затруднения.

К наиболее характерным языковым особенностям спортивно- ориентированного стиля речи можно отнести следующие:

1. Неизученные созначения многозначных слов. (To make one's appearance - дебютировать).

2. Отступление от обычного расположения главных членов предложения (инверсия). (The player who first scores more than half the points will be the winner. - Игрок, который первым набирает больше половины очков, будет победителем).

Дистантное расположение компонентов главных членов подобных предложений не всегда легко распознать и свести воедино при прослушивании, так как между подлежащим и сказуемым вставляются иногда целые придаточные предложения.

3. Случаи инверсии в повествовательных предложениях с вспомогательным глаголом have. (Never have I seen such a match. никогда не видел такого матча!)

Повествовательные предложения, в которых вспомогательные глаголы do, have ставятся в непосредственной препозиции к подлежащему и сказуемому, представляют, как правило, трудность для спортсменов, особенно при восприятии речи на слух.

4. Глагольные устойчивые словосочетания «глагол+существительное», «глагол+предлог+существительное», фразеологические словосочетания, выполняющие функции сложных предлогов, союзов или наречий.

5. Специфические субстантивированные словосочетания с основой существительного в препозиции. (Downhill slalom - скоростной спуск, football review - футбольное обозрение, home-team - командапринимающая сторона).

6. Переносные значения. (This athlete-arrow - этот спортсмен-стрела).

7. Пресуппозиции и постсуппозиции, которые не составляют часть эксплицитно выраженного значения высказываний. Они относятся к 
имплицитной, прямо не выраженной части информации и проявляются на уровне не ниже предложения. (I was mad about football for a while. Некоторое время мне очень нравился футбол).

8. Атрибутивно употребляемые существительные, стоящие перед существительным, которое они определяют. Количество таких существительных колеблется от 3 до 5. (Field hockey competition соревнования по хоккею на траве, ultralight flying competition results результаты соревнований по дельтапланеризму). Смысл подобных сочетаний необходимо пояснять учащимся.

При обучении общению особо следует сказать о фонетическом оформлении речи спортсменов-профессионалов. Темп английской речи значительно выше темпа речи русской, а спортивная речь (спортивные обозрения, комментарии, репортажи и пр.) характеризуется эмоциональностью, не всегда тщательной артикуляцией звуков и слов, пропусками глаголов-связок, сокращенным произношением некоторых слов. Нет необходимости выделять особое структурное звено занятия для постановки правильного произношения спортсменов-профессионалов. Возможно, нужна лишь некоторая корректировка навыков, которая будет происходить в процессе занятия и носить сопутствующий характер.

Одним из важнейших моментов при формировании коммуникативной компетенции следует считать качество учебного материала, которое учитывало бы особенности обучения говорению и аудированию. Учебные материалы по английскому языку для будущих специалистов в области физкультуры и спорта должны включать в себя профессиональный компонент, т.е. с их помощью спортсмен должен научиться осуществлять ряд профессиональных действий на английском языке в наиболее типичных ситуациях официального и неофициального общения. Так, перспектива будущего специалиста в области спорта участвовать в различных международных спортивных мероприятиях, осуществление судейства, перспектива тренировки в перспективном зарубежном спортивном клубе неизменно требует от спортсмена осуществления коммуникации, как в социально-бытовой, так и в профессиональной сфере.

$$
* * *
$$

1. Александров Д.Н. Формирование учебно-познавательной активности при обучении взрослых иностранным языкам / Методы интенсивного обучения иностранным языкам. -М, 1985. - Вып. 185.-4 C.

2. Беляева А.С. Обучение иноязычному профессионально- ориентированному речевому общению с учетом специфики физкультурных вузов. // Дисс... на соискание уч. степени доктора пед. наук, 2003. - $356 \mathrm{c}$.

3. Мильруд Р.П. Методология и развитие методики обучения иностранным языкам, Иностр. языки в школе. - 1995. - №5. - С. 13-18, С. 40.

4. Пассов Е.И. Коммуникативный метод обучения иноязычному говорению. М.: Просвещение, 1985. $-280 \mathrm{c}$.

5. Canale M. Theoretical bases of communicative approach to second language teaching and learning [Text] / M. Canale, M. Swain // Applied Linguistics. - 1980. -No.2. - P. 1-47.

Ивашова А.П.

Содержание коммуникативно-ориентированного обучения иностранному языку студентов СПО по направлению 53.02.04 «Вокальное искусство»

ФГАОУ ВО «Северо-Кавказский федеральный университет» (Россия, Ставрополь)

doi: $10.18411 / \mathrm{lj}-06-2021-172$

\section{Аннотация}

В статье рассматривается содержание коммуникативно-ориентированного обучения иностранным языкам студентов СПО, направленное на формирование у обучающихся иноязычной коммуникативной компетенции. 